\title{
O CONCEITO DE RESSENTIMENTO A PARTIR DE NIETZSCHE
}

\author{
Antonio Ruzza ${ }^{41}$
}

\begin{abstract}
RESUMO
O conceito de ressentimento foi estudado por Nietzsche para justificar a sua crítica à moral vigente, em particular aquela do Cristianismo. Deleuze se aprofundou no estudo e na interpretação da Genealogia da Moral, a partir dos conceitos nietzschianos de forças ativas e forças reativas presentes no indivíduo. Da relação entre tais forças resultará um homem forte ou fraco. O sujeito ressentido culpa alguém pelo próprio fracasso; deseja vingar-se, mas não tem força para isso. Prefere acomodar-se no papel de vítima; não vive o presente, porque não quer esquecer o passado, que fornece sentido à sua vida. Quando é influenciado pela religião, transforma o ressentimento em má-consciência, transfere a culpa para si mesmo, valoriza o sofrimento para pagar o pecado, inverte os valores de bom e mau, nega a vida. $\mathrm{O}$ conceito de ressentimento foi retomado pela psicóloga brasileira M. R. Kehl. Ela concorda com a análise de Deleuze quando trata do indivíduo (que é o principal interesse de Nietzsche), e depois estende a mesma concepção ao caso da sociedade. Aqui existem grupos de desfavorecidos, que normalmente devem ser considerados só resignados quando não agem; porém, quando partem para a ação sem fazer a análise correta dos males sociais, escolhem a solução errada de ressentir-se contra quem prometeu melhoras sem realizá-las, ou contra outros grupos de oprimidos, e acabam mantendo as injustiças e as desigualdades sociais, defendidas pelos favorecidos. Dessa maneira, seguindo essa linha, as considerações de Zizek sustentam que tais grupos acabam dando adesão a movimentos populistas, cujo líder explora o ressentimento (existente também nas classes médias e superiores, mas por motivos diferentes), para promover a política de conquista do poder.
\end{abstract}

Palavras-chave: Ressentimento, Resignação, Populismo.

\begin{abstract}
The concept of resentment was studied by Nietzsche to justify his criticism of the current morals, in particular the Christianity one. Deleuze went deeper into the study and interpretation of Moral's Genealogy, which is based on Nietzschean concepts of active and reactive forces presents on the individual. From the relationship between those forces, will arise a strong or weak man. The resentful man blames someone for his own failure; he wants to take revenge but lacks the strength to do so. He prefers to settle in the role of victim; he does not live in the present, because he does not want to forget the past, which gives his life meaning. When he is influenced by religion, he turns resentment into bad conscience, transfers guilt to himself, values suffering as payment for the sins, reverses the values of good and bad, denies life. The concept of resentment was taken up by the Brazilian psychologist Maria Rita Kehl. She agrees with Deleuze's analysis because he deals the subject from the individual forces (which is Nietzsche's main interest) and uses that same concepts for the case of society. Here there are groups of disadvantaged people, who should normally be considered only resigned when they do not act; however, when they take action without making the correct analysis of social ills, they choose the wrong solution resenting those who promised improvements without making them, or against other groups of oppressed people, and end up maintaining injustices and social inequalities, defended by the favored. Thus, following this line,

\footnotetext{
${ }^{41}$ Graduado em Engenharia pelo Politécnico de Torino (Itália) e em Filosofia pela USJT. Pós-graduado em "Docência para o ensino superior" pela UNIFAI. Mestre em Filosofia (Epistemologia da Política e do Direito) pela USJT. Doutor em Filosofia pela PUC. Docente de Filosofia no UNIFAI, no qual organizou vários grupos de estudo. Publicou Rousseau e a moralidade republicana no Contrato Social (Annablume, 2010); Em nome das lužes: um desafio à religião (Annablume, 2012); A crítica de MacIntyre à Modernidade: Liberalismo, Individualismo e teorias da Justiça (CRV, 2018). Publicou o artigo $A$ solução para o problema do absurdo em Albert Camus no livro Deus entre a Filosofia e a Teologia Contemporânea, de 2014, editado pela Appris.
} 
Zizek's considerations says that these kind of groups end up giving support to populist movements, whose leader exploits resentment (existing also in the middle and upper classes, but for different reasons), to promote the very policy of conquering power .

Keywords: Resentment, Resignation, Populism.

\section{INTRODUÇÃO}

O presente trabalho trata do tema do ressentimento, desenvolvido por Nietzsche e interpretado por Deleuze na obra Nietzsche e a Filosofia. Este tema é tão original e importante que o ressentimento foi considerado pelo autor da Genealogia da Moral a marca do Cristianismo. Ele foi incluído por Ricoeur (junto a Marx e Freud, que definiram o Cristianismo como ópio e ilusão, respectivamente) no grupo dos "filósofos da suspeita" por ter questionado, ou melhor, submetido a uma crítica radical valores, crenças e procedimentos aceitos até o seu século.

Cabe observar que o conceito de "ressentiment"42 foi usado antes por Dühring, autor de O valor da vida, que defende a ideia de que a justiça teria sua origem na disposição mecânica do ofendido para a vingança, o que significaria, portanto, que a justiça teria sua raiz em um sentimento considerado reativo: o ressentimento. ${ }^{43}$ Como veremos, o desejo de vingança é constitutivo desse sentimento. Para o entendimento do tema em questão, precisamos esclarecer outros conceitos importantes no pensamento nietzschiano, iniciando pelas forças ativa e reativa.

\section{FORÇAS ATIVAS E FORÇAS REATIVAS}

O ponto de partida é que a consciência não é uma faculdade humana que existe independente do mundo exterior, mas é o resultado ou efeito de algo mais profundo que acontece com o corpo, lugar de luta entre forças ativas e reativas (a distinção é qualitativa), de tipo biológico, social, político. Elas têm relação de dependência, não possuem natureza própria. Em suma, a consciência não é consciência de si mesma, nem de algo específico; ela vem da relação de algo inferior ou reativo, com algo superior ou ativo. ${ }^{44}$ Dependendo da quantidade, cada tipo de força poderá dominar ou ser dominada. Mesmo dominada, uma força continua sendo uma força que opera. Nada está definido de antemão, a hierarquia de forças surge na relação, existe um elemento de azar e de arbitrariedade.

\footnotetext{
42 Termo de origem francesa, pois não existe um correspondente em alemão.

${ }^{43}$ Nietzsche criticará esta concepção, sem disfarçar a sua antipatia pessoal por Dühring, definido um fanfarrão da moral: “após a instituição da lei, ao tratar abusos e atos arbitrários de indivíduos ou grupos inteiros como ofensa à lei, como revoltas contra a autoridade mesma, ela desvia os sentimentos dos seus subordinados, do dano imediato causado por tais ofensas, e assim afinal consegue o oposto do que deseja a vingança, a qual enxerga e faz valer somente o ponto de vista do prejudicado ... segue-se que justo e injusto existem apenas a partir da instituição da lei, e não, como quer Dühring, a partir do ato ofensivo" (Nietzsche, F. Genealogia da Moral, p. 59).

${ }^{44}$ Deleuze, G. Nietzsche y la filosofia, p. 60.
} 
As forças ativas não buscam o equilíbrio: elas arriscam, mostram alternativas, desafiam a segurança e a sobrevivência. Extrapolam a consciência, são quase inconscientes. Elas tendem ao poder, ${ }^{45}$ porque se apoderam, subjugam algo para criar um sentido novo, como o artista que dá forma a uma matéria. É a vontade de poder (elemento genealógico) que faz com que uma força domine ou dirija as outras, e ao mesmo tempo a faça obedecer dentro da relação que ela estabelece. ${ }^{46}$ As forças ativas são definidas nobres e fortes, porque permitem transformações. Mas, rompendo um equilíbrio, podem trazer dor e sofrimento.

As forças reativas ajudam a preservar a estabilidade e a continuidade, por meio do hábito e da memória. Em uma outra situação que implica uma mudança, elas possibilitam o triunfo dos fracos quando conseguem separar uma força ativa do seu poder, coisa que uma força ativa não faz, porque vai até a última consequência do poder e do desejo. ${ }^{47}$ Neste sentido, uma lei humana que limita um poder é uma força reativa; com referência a um diálogo entre Sócrates e Calicles, Deleuze observa:

Calicles se esforça em distinguir a natureza e a lei. Chama de lei tudo o que separa uma força do que a força pode fazer; a lei, nesse sentido, expressa o triunfo dos fracos sobre os fortes. Nietzsche acrescenta: triunfo da reação sobre a ação; de fato, tudo o que separa uma força é reativo; também, é reativo um estado no qual a força é separada do seu poder. Contrariamente, qualquer força que vai até o ponto final do seu poder, é ativa. Se uma força vai até o final, então, não é uma lei, aliás, é o contrário de uma lei.48

A força reativa faz com que, por exemplo, um escravo, mesmo continuando a ser um escravo, domine o senhor que deixa de ser senhor, a partir de valores apresentados como morais. A única possibilidade (desoladora para Nietzsche) parece aquela pela qual uma força reativa transforma uma força ativa em reativa (porque o escravo não deixou de ser reativo, mas transformou o senhor em reativo), sendo impossível o contrário: então, o homem é reativo por natureza?

Deixando esta pergunta sem resposta no nosso trabalho, ${ }^{49}$ observamos que Deleuze dá uma particular importância à distinção entre forças ativas e reativas. Entre as primeiras: ação, criação, esquecimento, saúde, risco, vontade, ousadia, energia, transformação, inovação, evolução ${ }^{50}$. Entre as segundas: necessidades biológicas, regras sociais, hábito, reprodução, consciência, memória, adaptação,

\footnotetext{
${ }^{45}$ Não é o poder político ou de dominação (como erradamente interpretado por alguns teóricos do racismo e do nazismo). Por isso, alguns comentadores e tradutores preferem usar o termo "potência".

${ }^{46}$ Deleuze, G. Nietzsche y la filosofia, p. 75. Quer dizer, também nas forças dominadas existe vontade de poder. Esta possui duas qualidades, negativa (leva ao niilismo, porque é vontade do nada) ou positiva. Qualquer uma das duas pode gerar as forças ativas ou reativas: não existe correspondência automática ou lógica entre afirmativo / ativo e negativo / reativo.

${ }^{47}$ Por exemplo, uma enfermidade é uma força reativa que limita as potencialidades do homem, diferente da saúde (força ativa) que lhe permite tentar realizar tudo que está em seu poder.

${ }_{48}$ Deleuze, G. Nietzssche y la filosofia, p. 85. A tradução da língua espanhola é nossa. Obviamente, Sócrates discorda: a lei permite que os fracos, juntos, formem "uma força mais forte do que aquela do forte", e isso não é contra a natureza.

${ }^{49}$ Nietzsche mostra a possibilidade oposta (o devir ativo por meio do eterno retorno, o além-do-homem), que não pode ser discutida aqui, pela limitação do nosso tema.

${ }^{50}$ Deleuze observa que Nietzsche se opõe a Darwin, que considerava a evolução algo passivo, reativo e imprevisível e recorria ao conceito de adaptação (também utilizado por Spencer). Em oposição, admira Lamarck, que entende o processo como resultado de uma força ativa de metamorfose.
} 
conservação, utilidade. Assim, na oposição de forças, a consciência exerce papel conservador a favor do “status quo". Paradoxalmente, a ciência deve ir na direção contrária à consciência, para poder avançar e quebrar paradigmas.

No sujeito de tipo ativo prevalecem logicamente as forças ativas; no reativo, as reativas. O tipo ativo pode usar as forças reativas para revidar, quando necessário. Ele sabe reagir a uma situação nova e que tende a prejudicá-lo. Se não conseguir, ele é um tipo reativo, que não toma a iniciativa de agir, somente quer preservar ou adaptar-se. O reativo se comporta passivamente conforme algo que o precede e o submete. ${ }^{51}$ Os dois tipos se enquadram na distinção nietzschiana de fortes e fracos, senhores e escravos ${ }^{52}$ : os primeiros lutam pelos objetivos que se põem, dizem "sim" à vida (como os protagonistas da tragédia grega, que lutam apesar de conhecer o destino que o levará à morte ou ao fracasso; o deles é um pessimismo ativo); os segundos se submetem ao poder dos outros, dizem "não" à vida (como os filósofos e os artistas do Romantismo, vítimas de um pessimismo passivo). Entre estes últimos está a figura do ressentido.

\section{O RESSENTIMENTO NO CASO DE UM INDIVÍDUO}

Na física, uma reação vem depois de uma ação. No mundo humano, o tipo ativo que se defende contra uma ofensa ou agressão, aciona as forças reativas (pode reagir). Mas estas podem limitar-se a “sentir" (sem movimento, sem ação), quando existe um entrave que impede a reação prática:

Em um estado normal ou saudável, as forças reativas sempre têm o papel de limitar a ação. Porém, inversamente, as forças ativas fazem explodir a reação. [...] $O$ ressentimento designa um tipo no qual as forças reativas prevalecem sobre as ativas. E só podem prevalecer de uma maneira: deixando de ser ativadas. [...] A reação deixa de ser ativada para converter-se em algo somente "sentido". ${ }^{3}$

O processo de nem agir, nem reagir provoca só o ressentir, que é uma manifestação doentia. ${ }^{54}$ Trata-se de uma patologia, de

[...] um auto-envenenamento por meio de sentimentos como inveja, rancor e ódio. É um envenenamento que ocorre quando esses sentimentos não podem ser descarregados para fora e se voltam para o interior do homem, onde - não digeridos - ficam sendo re-sentidos. É um tipo de resposta apresentada frente a um estímulo externo que não é apenas sentido, mas ressentido, ou que continua sendo sentido mesmo quando ele já não existe mais, ao menos externamente, pois, internamente (no subterrâneo daquele homem) permanece produzindo seus efeitos. Essa reação expressa certamente uma

\footnotetext{
51 É paradoxal: o tipo ativo sabe reagir; o reativo, não.

52 Podemos entender que esta distinção é moral, em oposição àquela tradicional e religiosa entre bons e maus.

${ }^{53}$ Deleuze, G. Nietzssche y la filosofia, p. 157-158. A tradução da língua espanhola é nossa.

${ }^{54}$ Canguilhem, autor de $O$ normal e o patológico, define que o sujeito saudável é aquele capaz de colocar em risco a estabilidade e não de somente manter a sua energia. Um bebê saudável é aquele que se mexe muito arriscando cair, se machucar, etc. Se passa o tempo parado, é porque não é saudável.
} 
patologia, pois ela não possui uma simetria com o estímulo que a produziu, sendo desproporcional em relação ao ato que a gerou..$^{55}$

O ressentimento tem assim uma natureza fisiológica e psicológica, com consequências no campo da moral vigente. Este é o caso do tipo reativo, no qual a reação se limita ao âmbito do sensível e deixa de ser ativada. Isto acontece porque ele é um tipo complexo, uma realidade biológica, física, histórica, social e política ao mesmo tempo.

O problemático neste processo é que a consciência recebe o impacto de algo que vem de fora; mas se está "cheia" (de ressentimento) não pode receber o novo, nem presta atenção. Para deixá-la receptiva, o recurso é o esquecimento das coisas que a marcaram negativamente. É interessante o destaque que Nietzsche dá ao esquecimento. Este não se dá só por inércia (que acontece pela passagem do tempo, ou pelas coisas sem importância). ${ }^{56}$ Trata-se de uma força ativa, produto de uma vontade de poder afirmativa, pela qual algo vivenciado é eliminado da consciência, deixando espaço para novas possibilidades; em particular para viver o presente e não resmungar sobre o passado, que está saturando a consciência. Esquecer (expulsar lembranças) é uma forma de ser saudável (assim como o corpo saudável expulsa os excrementos que o deixam "pesado, cheio").

Então, a lembrança faz com que o tipo de sujeito não esquece, só “ressente". Ela é considerada uma doença. A memória de uma ofensa do passado impede viver o presente; mas a mesma consideração vale pela lembrança contínua da promessa de um futuro (como a vida celeste). Na segunda dissertação da Genealogia da Moral, Nietzsche trata da promessa, que é uma lembrança do futuro. A fabricação do homem civilizado consiste em inculcar nele a memória do futuro, como condição de sociabilidade (que assim não é natural, como pensava Aristóteles). Isso não constitui um ruminar do passado, mas um atrelamento do que virá. Está na origem da ideia de responsabilidade. Não manter a promessa (esquecer do futuro) traz um sentido de culpa e uma punição severa: pela lembrança.

O ressentido vive em continuação a ação que o machucou. Para não cair no desespero, se convence de que o passado odiado é a razão da sua vida. Prefere continuar no papel cômodo de vítima do que superar a situação pelo esquecimento ou receber uma reparação que encerra o assunto. Será uma pessoa incapaz de admirar, respeitar, amar. Mas exige o tempo inteiro que lhe mostrem amor, como forma de benefício e compensação da sua dor.

Mas como se cria e como se alimenta o ressentimento? Deleuze destaca dois aspectos. O primeiro, topológico, "expressa a forma pela qual as forças reativas se subtraem à ação das forças ativas"; o segundo, tipológico, é quando "as forças reativas se opõem às forças ativas e as separam do seu poder". ${ }^{57}$

\footnotetext{
55 Paschoal, A. E. As formas de ressentimento na filosofia de Nietžsche, p. 14.

${ }^{56}$ Não devemos aqui generalizar. Existem fatos que não devem ser esquecidos, mas lembrados somente para tirar uma lição, evitar a repetição dos erros, fazê-los conhecer aos outros e continuar exigindo uma difícil reparação; não certamente para tirar as vantagens de se apresentar como a eterna vítima que tem sempre razão. Entre estes fatos: o Holocausto, a ditadura militar no Brasil, etc. Quando bem conduzidas, estas memórias não podem ser consideradas manifestações de ressentimento associadas a um puro desejo de vingança.

${ }^{57}$ Deleuze, G. Nietzsche y la filosofia, p. 175.
} 
Em suma, as forças reativas invertem a realidade, criam uma ficção na qual elas parecem superiores e fortes. Para executar este processo é necessário um artista! O primeiro destes artistas foi o sacerdote judeu, ${ }^{58}$ que inverteu os valores: bons são os miseráveis, os fracos; maus são os poderosos, os fortes. $\mathrm{O}$ processo é depois radicalizado pelo sacerdote cristão. Eles são os criadores do tipo ressentido, porque separam o "pecador" da sua força ativa pelo senso de culpa, e o deixam dependente de uma promessa de salvação; portanto, o deixam reativo, obediente, passivo, hibernado, hipnotizado, incapaz de reagir a uma ilusão. O sofrimento pode ser aliviado, mas o efeito psicológico é devastador.

$\mathrm{Na}$ sequência, as forças ativas, derrotadas, se voltam contra si e para dentro de si, transformando o ressentimento em má-consciência e produzindo sofrimento. Nietzsche observa que

Vejo a má-consciência como a profunda doença que o homem teve que contrair sob pressão da mais radical mudança que viveu - a mudança que sobreveio quando ele se viu definitivamente encerrado no âmbito da sociedade e da paz [...]. Todos os instintos que não se descarregam para fora voltam-se para dentro - isto é o que eu chamo interiorização do homem: é assim que no homem cresce o que depois se denomina a sua 'alma'. Todo o mundo interior, originalmente delgado, como que entre duas membranas, foi se expandindo e se estendendo, adquirindo profundidade, largura e altura, na medida em que o homem foi inibido em sua descarga para fora. ${ }^{59}$

A má-consciência substitui o ressentimento sempre por influência da religião: agora o culpado da dor é o indivíduo mesmo, porque pecou; o sacerdote, tipo ativo que o convenceu disso, é o único que pode aliviar a dor! Porque ele é o salvador, o pastor, o defensor do rebanho doente. A cura consiste na ascese, na renúncia de si, na renúncia à vida: viver no medo e arrepender-se de todas as manifestações vitais. Afinal: em querer o nada. É o momento negativo do niilismo. O cristão inventa o “pecado” para interiorizar mais o senso de "culpa" inventado pelos judeus. Assim muda o valor e a direção da força. O papel do sacerdote ascético não se limita a dominar os fracos deixando-os ressentidos e com máconsciência. Ele deverá combater os fortes e derrubá-los a partir da moral que falsifica os valores. O resultado é a autodiminuição da humanidade. Em todo caso, mesmo neste querer o nada, o ideal ascético fornece um sentido à vida, é sempre uma manifestação de vontade de poder, mesmo que seja negativa.

Isto porque, como bem observa Deleuze ${ }^{60}$, a má-consciência faz mudar o sentido do sofrimento, que é ampliado e valorizado, por isto desejado; vale mais a dor interna do que a física, e ela é oferecida à Deus. Um sofrimento elevado é preferível a uma felicidade medíocre. O paradoxo é uma crueldade contra si mesmo, um torturar-se pelo remorso na espera da redenção. A dor é usada para argumentar contra a vida, considerada culpada de um pecado. ${ }^{61}$ Pela visão religiosa, a dor tem um sentido e facilita aceitar uma

\footnotetext{
${ }^{58}$ Considerações desse tipo foram utilizadas de forma distorcida pelos nazistas para dar um verniz filosófico ao antissemitismo. Em várias ocasiões, Nietzsche se mostrou hostil ao antissemitismo e ao pangermanismo, que se tornaram mais radicais após a unificação dos estados alemães e a proclamação do Segundo Reich em 1870.

${ }^{59}$ Nietzsche, F. Genealogia da Moral, p. 67.

${ }^{60}$ Deleuze, G. Nietzsche y la filosofia, p. 181.

${ }^{61}$ No mundo dionisíaco, pelo contrário, a dor faz parte da afirmação da vida. Nietzsche tratou da oposição entre dionisíaco e apolíneo em $O$ Nascimento da Tragédia.
}

Revista Lumen, v. 5, $\mathrm{n}^{\circ}$ 9, Jan./Jun. - 2020 - ISSN: 2447-8717 
vida de sofrimento. O culpado acha que a sua vida tem sentido só se a dor tem sentido, por exemplo, de expiação. Para Nietzsche, deve ser dado outro sentido à dor, para que a vida não seja só senso de culpa (culpa do outro para o ressentido; dele próprio para a má-consciência). Assim, a vida seria liberada do peso da moral judaico-cristã.

A psicóloga Maria Rita Kehl fornece uma interessante resposta para a mesma pergunta: como se cria e como se alimenta o ressentimento. Ela inicia pela definição: ressentimento (que para ela não é um conceito da psicanálise), é um sentimento duradouro, cultivado e desejado; consiste em

[...] atribuir a outro a responsabilidade do que nos faz sofrer. Um outro a quem delegamos, em um momento anterior, o poder de decidir por nós, de modo a poder culpá-lo no que venha a fracassar. Nesse aspecto, o ressentido pode ser tomado como o paradigma do neurótico, com sua servidão inconsciente e sua impossibilidade de implicar-se como sujeito de desejo. Mas essa é uma definição genérica demais. ${ }^{62}$

Continuando, Kehl afirma que o ressentido não quer esquecer, ou quer não esquecer. Ele não esboça reação (no fato ou na palavra), porque neste caso a dor poderia ser aplacada (e depois esquecida), coisa que ele não quer, porque a sua é uma vontade de poder negativa, apesar de que a falta de reação lhe traz sofrimento. Prefere se manter no papel de vítima injustiçada.

O que lhe resta é alimentar o desejo de vingança, mas isso fica só no desejo preso dentro dele, e o envenena, porque ele é incapaz de agir, de executar a vingança. A vingança adiada fica no imaginário e no simbólico: espera que o culpado sinta remorso e sofra; ou que Deus envie a punição. Assim,

Este desejo de vingança recusado é o núcleo doentio do ressentimento nietzschiano. Uma vez que não se permite reagir, só resta ao fraco - ressentir. O ressentimento é uma doença que se origina do retorno dos desejos vingativos sobre o eu. É a fermentação da crueldade adiada, transmutada em valores positivos, que envenena e intoxica a alma, condenando-a ao não esquecimento. Nem por isso o ressentido está livre de, também ele, padecer da mesma má-consciência que ele gostaria de incutir nos fortes. ${ }^{63}$

Até a existência do mundo (que não compartilha a sua dor) o ofende: este sujeito gostaria de vingar do mundo, mas não sabe reverter a situação. Ele não se sente à altura de responder ao agressor, porque se considera fraco, inferior. Esta sensação o mantém numa espécie de

[...] dependência infantil com o outro, supostamente poderoso, a quem caberia protegêlo, premiar seus esforços, reconhecer seu valor. O ressentimento também expressa a recusa do sujeito em sair da dependência: ele prefere ser protegido, ainda que prejudicado, a ser livre, mas desamparado. ${ }^{64}$

\footnotetext{
${ }^{62}$ Kehl, M. R. Ressentimento, p. 13.

${ }^{63}$ Kehl, M. R. Ressentimento, p. 126.

${ }^{64}$ Kehl, M. R. Ressentimento, p. 18. Esta observação pode ser aplicada à dupla senhor / escravo.
} 
Um outro aspecto destacado por M. R. Kehl é que o ressentido é um derrotado que não se vê como derrotado (de forma justa e honesta), mas como vítima inocente de um vencedor ardiloso que usou de forma desproporcional (isto é, abusou) a sua força. ${ }^{65}$ Este inimigo pode ser um indivíduo ou a sociedade inteira, que não soube reconhecer as suas qualidades e talentos. Assim, o fraco não é culpado pelo seu fracasso e se vê moralmente superior, isto é, bom. Nunca se arrepende, pois neste caso seria responsável de parte do acontecido. Se for religioso, ela espera a compensação pela justiça divina. Mesmo sendo o perdão uma virtude cristã, ele não perdoa, porque o perdão pode trazer o esquecimento que ele não quer. Afinal, este sujeito divide o mundo entre bons (ele) e maus (os outros), entre verdade e mentira, divisões 49 dualísticas que Nietzsche ${ }^{66}$ rejeita como recurso dos fracos para dominar ou imobilizar os fortes, apresentados como maus (cruéis, impiedosos, injustos, etc.). Aqueles conceitos de bom e mau não são naturais, mas são o resultado de uma luta de forças, com a vitória das forças reativas e da sua vontade negativa de poder, que impõe uma moral inventada ou fabricada. ${ }^{67}$ Trata-se da moral escrava que transforma em mérito a fraqueza:

A impotência que não acerta as contas é mudada em bondade; a baixeza medrosa em humildade; a submissão àqueles que se odeia em obediência (há alguém que dizem impor esta submissão - chamam-no Deus). O que há de inofensivo no fraco, a própria covardia na qual é pródigo, seu aguardar na porta, seu inevitável ter de esperar, recebe aqui o bom nome de 'paciência', chama-se também a virtude; o 'não poder vingar-se' chama-se 'não querer vingar-se', talvez mesmo perdão. [...] eles me dizem que sua miséria é uma eleição e distinção por parte de Deus, que batemos nos cães que mais amamos; talvez essa miséria seja uma preparação, uma prova, um treino, talvez ainda mais - algo que um dia será recompensado e pago com juros enormes, em ouro não! Em felicidade. ${ }^{68}$

Por esta moral do ressentimento, o fraco, a partir da sua derrota, quer até despertar no forte o afeto negativo da má-consciência, para que o forte se sinta culpado de usar a sua força vital. $\mathrm{O}$ autor da Genealogia da Moral julga esta pretensão ser absurda: valorizando o instinto, que é inato ou inconsciente, o forte não pode segurar a sua potência vital ou sentir-se culpado ${ }^{69}$. Isso não significa oprimir o outro:

Se existe uma moral em Nietzsche, este eterno doente, este homem recluso e solitário que proclamava a vida, esta moral vai no sentido de exortar os fracos a que se fortaleçam - enquanto sua forma de luta consiste em justificar e valorizar sua fraqueza, estarão condenados ao ressentimento. ${ }^{70}$

\footnotetext{
${ }^{65}$ É possível que um forte seja derrotado: mas ele reconhecerá a superioridade do inimigo e não ficará ressentido.

${ }^{66}$ Para Deleuze, ética e moral são conceitos diferentes em Nietzsche. A primeira avalia o modo de existência, bom ou ruim, a partir do julgamento dos fortes. A segunda é definida a partir de uma tábua de valores prefixada sobre o bem e o mal, construída para desativar as forças ativas. Como dito, a moral vigente julga mau aquele que age e não se pergunta quanto às consequências negativas sobre o fraco. Afinal, a moral é identificada com o moralismo.

${ }^{67}$ Kehl, M. R. Ressentimento, p. 110-111.

${ }^{68}$ Nietzsche, F. Genealogia da Moral, p. 34.

${ }^{69}$ Já Voltaire observava que um tigre não podia ser condenado por usar a força da qual a natureza o dotou. Ele não está abusando dela.

${ }^{70}$ Kehl, M. R. Ressentimento, p. 119.
} 
Mas, até que haja (caso haja, porque é só uma possibilidade) uma introdução de novos valores, domina o "moralista": um ressentido, um derrotado na luta da vida (a qual ele diz “não"), que inventa um sujeito julgado bom somente se for sofredor, humilde, servil e resignado.

\section{O RESSENTIMENTO NO CASO DE UM GRUPO OU DE UMA SOCIEDADE}

O processo pelo qual se desenvolve o ressentimento é também cultural, porque a sociedade e a religião, para manter a ordem e em troca de proteção (segurança física, assistência social e espiritual), fazem com que o sujeito renuncie aos instintos vitais e não reaja, mas se console na eventual derrota na luta da vida e valorize as experiências negativas do passado, até se orgulhe delas, na esperança de reconhecimento por parte da sociedade (com relação à injustiça sofrida) ou um prêmio na vida futura. $\mathrm{Na}$ passividade ${ }^{71}$, toda a sua energia fica esgotada em ruminar o passado e vislumbrar uma vingança (comportamento não propriamente religioso) que em todo caso não chegará. O homem civilizado vive entre culpar os outros ou a si mesmo, sob a tutela moral do sacerdote e da autoridade política. Sobra só o ressentimento e os seus produtos (má-consciência, rancor, ódio, autodesvalorização), o olhar do mundo só a partir do fato que o machucou, a servidão voluntária: em suma, a conservação de uma vida diminuída.

Vimos que o esquecimento é uma força ativa, um ato, um poder; ${ }^{72}$ é algo intempestivo que irrompe no indivíduo quebrando o freio imposto pela tradição; não é a mera eliminação da lembrança ou de conhecimentos históricos. Então, não diz só respeito ao indivíduo, mas a uma sociedade inteira, que arrisca ficar atrofiada pelo fardo do passado (a tradição) e pela recusa do novo. Este tipo de cultura é só reativa, quer conservar a tradição: não tem futuro.

Existe, entretanto, uma situação que envolve grupos de indivíduos e para o qual precisa verificar se ela pode ser considerada uma manifestação de ressentimento. M. R. Kehl observa que em uma situação de opressão, em que todos os direitos são suspensos e os indivíduos desumanizados (como sob uma ditadura violenta ou em um campo de concentração), fica impossível esboçar uma reação, que certamente fracassaria por motivos objetivos; assim, aparece o desejo de vingança, que não pode ser realizado até que não aconteça um fato novo (como a queda do regime opressor ou a libertação do campo por parte de um exército). Mas “esta vingança adiada não é a mesma das elucubrações mentais a que se entrega o ressentido, psicologicamente impotente para dar outro destino à sua amargura". ${ }^{73}$ Chega o momento em que ela se realiza, por exemplo em forma de processo ou de execução sumária, como aconteceu com muitos nazifascistas derrotados e outros ditadores. Conclusão: essas pessoas oprimidas que sofreram e alimentaram desejo de vingança não podem ser consideradas ressentidas; no máximo, são resignadas ou abatidas, na espera da desforra.

\footnotetext{
${ }^{71}$ Deleuze esclarece que "passivo" não significa inativo, mas não ativado (p. 166).

${ }^{72}$ Como aquele de um jovem que esquece os conselhos e as experiências do pai e vive a sua própria vida.

${ }^{73}$ Kehl, M. R. Ressentimento, p. 21.
} 
No caso de grupos sociais desfavorecidos, como os trabalhadores pobres ou desempregados no sistema capitalista, tampouco podemos falar de ressentimento, caso eles aceitem a situação de submissão e degradação, à qual não podem se opor pela situação de inferioridade física, e se limitam a queixas genéricas e raivosas contra as injustiças sofridas. Mas uma certa visão liberal considera que os losers (os perdedores que fracassam na luta pelo sucesso, apesar de todas as possibilidades que a sociedade capitalista oferece, no entendimento desta) acabam necessariamente no ressentimento, talvez confundindo-o com uma revolta genérica e individualista contra a sociedade e o mal-estar que ela provoca; ou com uma atitude de recusa dos seus valores morais. Em suma, a visão liberal associa automaticamente o fracasso social ao ressentimento.

Mesmo não compartilhando a visão liberal sobre estes grupos, M. R. Kehl reconhece que é possível a queda no ressentimento, mas por um outro motivo fundamental. O seu exemplo é de quando a promessa de igualdade feita por elementos revolucionários ou reformistas faz cair a resignação pela qual a desigualdade é considerada uma vontade divina ou de qualquer maneira algo necessário e imutável; mas depois esta promessa não é mantida, talvez por ser utópica ou por manter-se no aspecto formal ou porque o adversário é mais forte. Surgem assim "manifestações reativas, ressentidas, que expressam insatisfação popular, mas não levam a nenhum resultado efetivo no sentido do aperfeiçoamento dos dispositivos da democracia" ${ }^{\text {74 }}$, que poderiam garantir uma efetiva redução das desigualdades. Os cidadãos ficam culpando tudo e a todos (sobretudo o governo), mas não pensam que eles têm uma parcela de culpa por causa do seu desinteresse em participar da política.

Neste sentido, o ressentimento social é um produto típico da sociedade contemporânea e democrática, mais suscetível a decepções e à solidão. No mundo antigo, o conceito não era aplicável; Aristóteles, na sua análise das emoções, trata da raiva e da inveja (que são só aspectos secundários do ressentimento). A primeira é endereçada contra um indivíduo que ofende alguém que lhe é superior por status, social ou moral; a segunda expressa um desejo, não de possuir um bem, mas de que o outro não o possua. ${ }^{75}$ Em sociedades estáticas e rígidas que se prolongam desde o fim do mundo antigo até a Revolução Francesa, a aceitação quase fatalista das condições de vida faz com que a pessoa seja razoavelmente acomodada na sua resignação e na aposta na vida celeste; ela nem tem sentimento de inveja ou raiva contra os superiores (ou contra os iguais, porque não existe ainda o espírito de competição). Ser resignado não traz por si ressentimento social, no máximo uma insatisfação individual que as autoridades controlam com facilidade.

Porém, agora que a sociedade vislumbra um grande leque de possibilidades e oportunidades, Max Scheler observa que na modernidade "cada um tem o direito de se julgar igual ao outro, mas não é de fato capaz disso". ${ }^{76}$ Este "cada um" é o homem fraco e reativo nietzschiano. Ele acaba culpando os

\footnotetext{
${ }^{74}$ Kehl, M. R. Ressentimento, p. 23.

${ }^{75}$ Konstan, D. Ressentimento - História de uma emoção. In: Memória e (Res)sentimentos, p. 63-65.

${ }^{76}$ Scheler, M. L'homme du ressentiment, p. 22. Ele considera o ressentimento ser um autoenvenenamento psicológico por meio do silêncio acusador e da fantasia vingativa. A “paixão pela igualdade” levada ao extremo foi considerada perigosa por vários
} 
outros (por exemplo, aqueles que prometeram a igualdade: os líderes revolucionários ou o Estado democrático; mas não aqueles que causam a desigualdade! Trata-se de uma análise incorreta das condições sociais) pela incapacidade de realizar aquelas promessas; ${ }^{77}$ entende que ele pessoalmente não tem nenhuma responsabilidade no fracasso, porque é só um objeto passivo que deve ser protegido pelo Estado paternalista; foi só ingênuo em acreditar.

Este sentimento reativo não permite transformar as condições que provocam a desigualdade; no máximo provoca um protesto impotente, ${ }^{78}$ espontâneo e sem objetivos, às vezes contra os semelhantes do seu grupo (que conseguiram uma pequena melhoria; por isto causam inveja) e não contra os superiores responsáveis pelas suas desgraças; nunca provoca uma revolução que requer um grau de consciência diferente e uma indignação sincera pelas injustiças sociais. Ao contrário, o ressentido pode ser uma arma nas mãos da reação conservadora ou de movimentos autoritários, populistas, totalitários. ${ }^{79}$ Afinal, o ressentido é funcional ao sistema e à classe dominante (que depois ele assume como ideal e referencial), porque não gosta de arriscar as pequenas conquistas, não age, não participa da vida política, mas “deseja a ordem - por isso é compatível com o conservadorismo - contando que possa beneficiar-se dela, nem que seja na condição de vítima". ${ }^{80}$

Em suma, M. R. Kehl insiste que a indignação pela injustiça social não é uma forma de ressentimento, mas pode resultar nele quando não se compreende que o Estado democrático não tem recurso para alcançar a igualdade máxima e realizar todos os desejos humanos, mas só oferece mais oportunidades para um avanço social, tanto coletivo quanto individual; ou quando não se compreende que a ordem justa não depende só da vontade dos governantes democráticos ou dos revolucionários, mas da participação ativa do cidadão. ${ }^{81}$ Esta concepção republicana é a negação da passividade e da indiferença do indivíduo no Estado liberal, bem como da submissão incondicionada a um líder totalitário. No primeiro caso (dominante na atualidade), a psicóloga se pergunta: a notória oposição de Nietzsche à democracia não se justifica pelo fato de que "os Estados democráticos enfraquecem a capacidade de intervenção política (como "vontade de potência") das massas"? Por que eles "se estruturam a partir do enfraquecimento, da destituição da capacidade de ação, da tutela da maior parte da população"? ${ }^{82}$

\footnotetext{
filósofos políticos de tendência republicana ou liberal (Maquiavel, Montesquieu, Tocqueville), sem concluir que leva a forma de ressentimento, conceito desconhecido nas suas épocas.

77 É interessante observar que a política decepciona pelas promessas não mantidas, mas isto não acontece com a religião, cujas promessas são para uma outra vida, portanto não verificáveis.

${ }_{78}$ É aquela que Bourdieu define uma revolta submissa.

$79 \mathrm{O}$ nazifascismo encontrou seguidores entre os ressentidos sociais porque lhes ofereceu uma identidade para compensar um sentimento de inferioridade, frustração, insignificância; porque lhes forneceu a possibilidade de exercer violência sobre os mais fracos. No caso do nazismo (não somente alemão), o antissemitismo é uma forma de ressentimento social contra um grupo considerado inferior, mas que estava competindo em condições de igualdade e com melhores resultados, em um momento de crise social e econômica.

${ }^{80}$ Kehl, M. R. Ressentimento, p. 288.

${ }^{81}$ Desta maneira, ele declara opor-se a várias correntes conservadoras e tradicionalistas, que condenam a modernidade, a democracia, o liberalismo, o socialismo, etc. que (na opinião de tais correntes) teriam aumentado, pela ilusão, a insatisfação do homem moderno (e o seu eventual ressentimento), provocando instabilidade social e revoluções.

${ }^{82}$ Kehl, M. R. Ressentimento, p. 299.
} 
Claramente, o autor da Genealogia da Moral tem outra visão. Os fracos se organizam e agora "o ressentimento não é uma descrição do homem que não reage, mas da própria ação daquela sede de vingança atuando como uma vontade de poder operante que busca dominar e impor-se sobre as demais por meio de uma estratégia que consiste em apresentar-se como a própria justiça." $\$ 3$ Os ressentidos impõem, por exemplo, como sendo justo o ideal de igualdade, nas suas várias formas: cristã, socialista, anarquista, democrata, até liberal. Eles alimentam a moral do ressentimento que se apresenta como a única verdadeira, mas que serve só a derrubar os fortes, porque é a moral do rebanho. É uma manifestação de niilismo reativo.

\section{A EXPLORAÇÃO DO RESSENTIMENTO POR PARTE DO POPULISMO}

Nas primeiras décadas do século XX, avançou um movimento político e social chamado de populismo. Ele abrange uma pluralidade de fenômenos e apresenta uma mescla de elementos conservadores, liberais, fascistas, nacionalistas e até socialistas, prevalecendo um ou outro elemento, conforme a situação política e econômica de cada país. Ele não tem uma base social especial ou uma orientação ideológica particular, opera numa realidade social heterogênea e flutuante, desafia uma normalidade política e social em crise, articula demandas sociopolíticas fragmentadas e deslocadas rumo a alguma forma de unidade. Isso dificulta dar uma definição precisa do termo, sendo preferível apresentar uma lista de traços relevantes, não necessariamente presentes em todas as formas ou um todos os países ou em todas as épocas. ${ }^{84}$ Porém, um elemento comum a todas essas situações parece ser o ressentimento, tão característico do "homem do subsolo" de Dostoiévski que sonha em vingar-se dos bem-sucedidos. Trata-se de uma emoção que deriva da percepção de que o grupo ao qual se pertence está em uma posição injustamente subordinada em uma hierarquia de status, ou que perdeu o status: tal percepção é aplicável, por exemplo, àqueles que criticam a igualdade de direitos, que lhe fez perder a superioridade que acreditavam ter sobre as minorias (negros, refugiados, etc.).

O ressentimento encaminha a pessoa para os braços de um líder populista. Este faz largo e eficiente uso da retórica e da mentira (pelo desinteresse ou negação dos fatos mais evidentes), e convence o chamado "povo" (mas que na realidade é só uma parcela) de que ele é o único capaz de resolver todos os problemas, e com soluções fáceis.

Esse líder se aproveita de certos sentimentos depressivos das pessoas, provocados pelas políticas neoliberais que não encontraram oposição após o fim do "socialismo real": status ameaçado pela globalização e automação, expectativas de melhorias contínuas não atendidas, frustração, amargura, ansiedade, fracasso na vida profissional ou privada, apreensão econômicas quanto ao futuro, perdas de

\footnotetext{
${ }^{83}$ Paschoal, A. E. As formas de ressentimento na filosofia de Nietz̧sche, p. 23. O comentador se refere à segunda dissertação da Genealogia da Moral.

${ }^{84}$ Este é um dos motivos pelos quais colocamos o populismo do nosso século no campo da extrema direita.
}

Revista Lumen, v. 5, nº 9, Jan./Jun. - 2020 - ISSN: 2447-8717 
privilégios conquistados, sensação que ninguém se interessa por elas ou que são desprezadas porque não acompanham os "novos tempos". A esta pessoa ressentida, que se considera vítima não responsável e sente raiva, inveja, humilhação, impotência e, sobretudo, ódio, o líder populista apresenta um inimigo culpado de tudo a partir da divisão entre "nós" e "eles". Este inimigo é escolhido entre minorias vulneráveis e grupos historicamente discriminados: negros, mulheres, imigrantes, refugiados; minorias étnicas, culturais, linguísticas e religiosas; todos eles deveriam continuar submissos e inferiorizados; porém, conquistaram uma certa igualdade de direitos (ou até direitos diferenciados) que faz perder oportunidades, quebra a identidade e homogeneidade do "povo", põe em crise um conjunto de valores e certezas; afinal, provocam o ressentimento contra o grupo minoritário ou o Estado como um todo.

O objetivo do líder populista, que em primeiro lugar busca o poder pessoal ou da sua família, é de dividir, não de unir; então, encontra seguidores em todas as classes sociais, apresentando a cada uma um discurso antissistema e um inimigo diferente, conforme a situação do momento. Para atrair os estratos populares e empobrecidos, ele ataca as "elites", as finanças, a democracia liberal que não atende às expectativas, as instituições, a ordem estabelecida. Para a classe média, ameaçada no seu status confortável pela crise econômica, ele se apresenta nacionalista, antiglobalista, xenófobo. Para as classes dominantes, as mais beneficiadas pelo neoliberalismo, ele apresenta um discurso sensível a ideias fascistas de supremacia, de segregação, contra os direitos civis e humanos das classes humildes e das minorias.

Assim, o ressentimento é sempre endereçado pelo líder populista contra um inimigo. Porém, no caso das classes desfavorecidas, trata-se do inimigo errado, como bem observou Slavoj Zizek, para o qual a ira populista de direita é uma forma distorcida de luta de classes, como já aconteceu com o fascismo, que atraiu adeptos em todas as classes sociais, cada uma por um motivo diferente. Por exemplo, ele observa que Trump (um rico trambiqueiro) posa de defensor dos despossuídos e dos fracassados da globalização, porque quer impedir que eles próprios se defendam (e na direção certa!). ${ }^{85}$

\section{O RESSENTIMENTO DO HOMEM REVOLTADO}

Vimos antes que Scheler considera que o ressentimento é o produto de promessas não mantidas (como aquela da igualdade) e o define como uma autointoxicação colorida pela inveja. É uma atitude mental duradoura que se transforma em arrivismo ou amargura. É geralmente ressentimento contra si mesmo porque faz usufruir de uma dor que o sujeito gostaria que atacasse o objeto do seu rancor. Depois, Scheler o identifica de forma absoluta com o espírito de revolta. Em suma, o revoltado é um ressentido que não sabe adaptar-se à ordem social e aos seus valores.

Mesmo concordando com a definição e as primeiras observações acima, Camus, no Homem revoltado, discorda de que a revolta de um indivíduo seja produto do ressentimento. A revolta marca o direito de

${ }^{85}$ Zizek, S. A Tentação Populista, em A Grande Regressão, p. 295-298.

Revista Lumen, v. 5, $\mathrm{n}^{\circ}$ 9, Jan./Jun. - 2020 - ISSN: 2447-8717 
não ser oprimido, além de um nível tolerável; parte da consciência de uma situação, isto é, de um indivíduo informado que não vê outras alternativas; provoca uma ação racional em nome de um valor que julga comum a todos os homens, aceitando o sacrifício; não é uma forma de egoísmo ou individualismo; é possível em sociedades de igualdade teórica, mas não de fato (as ocidentais democráticas); é impossível no mundo do sagrado, no qual não existem "problemas" e tudo segue uma ordem programada. Camus acredita na revolta metafísica, aquela que, frente às injustiças do mundo, escolhe uma alternativa diferente da resignação cristã, do suicídio, da revolução sangrenta. A revolta metafísica fornece um sentido à vida e faz com que o sujeito seja o que quer ser, para tornar-se o que é, enquanto as outras três alternativas deixam a escolha e a decisão nas mãos dos outros: Deus, a morte, o ideal irrealizável. ${ }^{86}$

Assim, Camus pode afirmar que "aparentemente negativa, já que nada cria, a revolta é profundamente positiva, porque revela aquilo que no homem sempre deve ser defendido". ${ }^{87} \mathrm{O}$ revoltado não é fraco, nem reativo, e não se encaixa na definição nietzschiana de ressentido.

\section{CONCLUSÃO}

Vimos nesse pequeno trabalho a explicação original nietzschiana (bem esclarecida por Deleuze) do conceito de ressentimento, que é característico de um tipo de homem julgado fraco e reativo. Mas nem por isso menos perigoso, tanto que consegue impor a sua vontade negativa de poder aos fortes, dominando-os por meio de valores definidos como autenticamente morais e verdadeiros; em particular, aqueles religiosos do mundo judaico-cristão.

Transportando as observações de Nietzsche à sociedade hodierna em crise, acompanhamos as observações de M. R. Kehl, tanto no caso de um indivíduo isolado quanto de grupo sociais desfavorecidos, que acabam caindo no ressentimento quando não conseguem uma interpretação correta da realidade, isto é, das causas da sua situação social; para ela, a falta de ação provoca a manutenção daquela situação. Esta interpretação é compatível com aquela de Zizek, que entende que o populismo, explorando o ressentimento, consegue a manutenção da sociedade desigual, endereçando os desfavorecidos contra o inimigo errado, e atraindo os favorecidos que desejam eliminar as conquistas sociais das minorias. Então, a situação atual, com tantos indivíduos ressentidos pelos mais diferentes motivos, revela-se parcialmente funcional para as sociedades contemporâneas dominadas pela visão liberal e pelo sistema capitalista, que não fica ameaçado na sua essência.

Finalmente, o nosso estudo foi complementado dando destaque à discordância entre Scheler e Camus, porque este nega que o homem revoltado possa ser considerado um ressentido. Ao contrário, se a revolta é metafísica, ela fornece um sentido à vida do indivíduo.

\footnotetext{
${ }^{86}$ Extraído do artigo de Ruzza $A$ solução de Albert Camus para o problema do absurdo.

${ }^{87}$ Camus, A. O bomem revoltado, p. 32.
} 
A partir de todas estas considerações, podemos concluir que o ressentimento é um mal, ou pelo menos uma característica, da sociedade contemporânea? A resposta é sim nos dois casos: no primeiro, porque impede ao indivíduo de realizar as suas potencialidades contentando-se em ficar no rebanho, ou partindo para uma ação de consequências perigosas; no segundo, porque alimenta o fenômeno populista, uma ameaça para a sociedade democrática com as suas liberdades e direitos, como já aconteceu com o nazifascismo no século passado.

\section{Referências}

BRESCIANI, Stella, e NAXARA, Márcia. (org.). Memória e (Res)sentimento. Campinas: Unicamp, 2001.

CAMUS, Albert. O homem revoltado. Rio de Janeiro: Record, 2005.

DELEUZE, Gilles. Nietz̧sche y la filosofia. Barcelona: Anagrama, 1986.

KEHL, Maria Rita. Ressentimento, São Paulo: Casa do Psicólogo, 2004.

NIETZSCHE, Friedrich. Genealogia da Moral. São Paulo: Companhia de Bolso, 2015.

PASCHOAL, Antonio Edmilson. As formas de ressentimento na filosofia de Nietssche. In: Philósophos 13, 2008

RUZZA, Antonio. A solução de Albert Camus para o problema do absurdo. In: Deus entre a Filosofia e a Teologia contemporânea. Curitiba: Appris, 2014

SCHELER, Max. L'bomme du ressentiment. Paris: Gallimard, 1958.

ZIZEK, Slavoj. A grande regressão. São Paulo: Estação Liberdade, 2.019 